\title{
33. シングルパス用限外濾過自動制御装置の試作
}

\section{目的}

最近, 透析技衔の進歩は, Dialyzer の水分 除去能のバラッキを改善し, 比較的容易に患者 から望严の除水をえることができるようにな ってきている。しかし，通常の血液透析におい ては，Dialyzer の種類や透析中の患者の状態 によって安定した限外㥁過圧を設定できず，十 分な除水をえることができないことがしばしば ある.このような問題を解決するため，われわ れは, single pass 方式に扔いて, 透析前に設 定した除水量を確実に除水できる装置を試作し たので報告する。

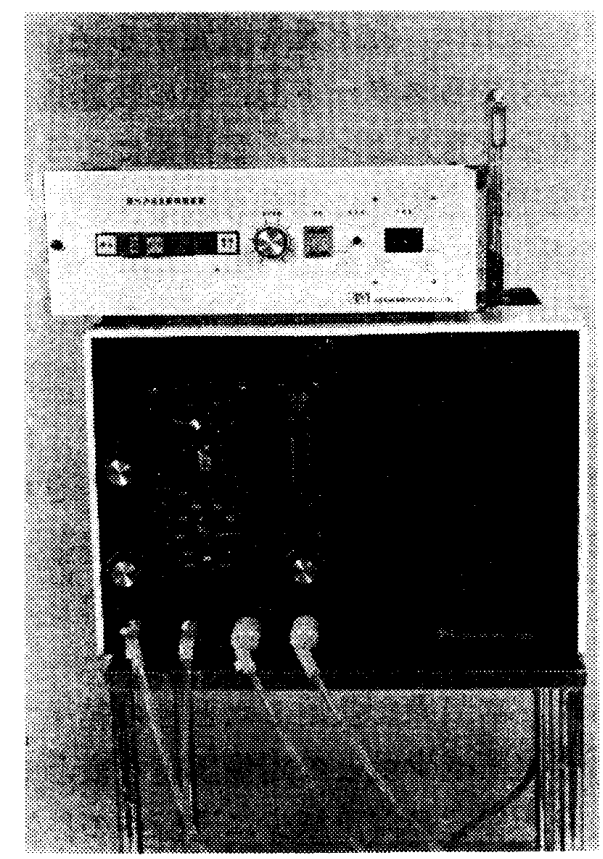

写真 1
星野敏 久* 阿岸鉄三* 金子岩和* 会田和夫*江良和雄*太田和夫* 西村良 江 ${ }^{* *}$

\section{装置の構成ならびに原理}

本装置は，連続的に除水量を測定し，限外滤 過圧をコントロールするモニタ部と, 透析前に 毎分の除水量を設定し，モニタ部で測定された 除水量を毎分の除水量として表示し，同時に限 外濾過圧を自動的にコントロールするレギュレ 一タ部で構成されている。

図 1 は，モニタ部を模式図化したものであ る，本装置は，除水量を測定するための，Dialyzer 前後の $500 \mathrm{~m} l$ タンク, 透析液の流れを切 換える 4 個の電磁弁, 陰圧ポンプ, 陰圧制御用 のモータバルブおよび各種のセンサから構成さ れている.

除水量の測定は，具体的にまず，周期的な電 磁弁の切換えにより, Dialyzer に入る前の $\mathrm{Ti}$ タンクの透析液を Dialyzer に流し, Dialyzer から出た透析液をTo タンクで定量する。 To タンクで限外滤過された量 $\mathrm{q} \mathrm{m} l$ は, オーバー フローしセンサで電気抵抗に変換される。その とき, $\mathrm{Ti}$ タンクの光電素子による上部センサ と下部センサで, $500 \mathrm{~m} l$ の透析液が流れた時間

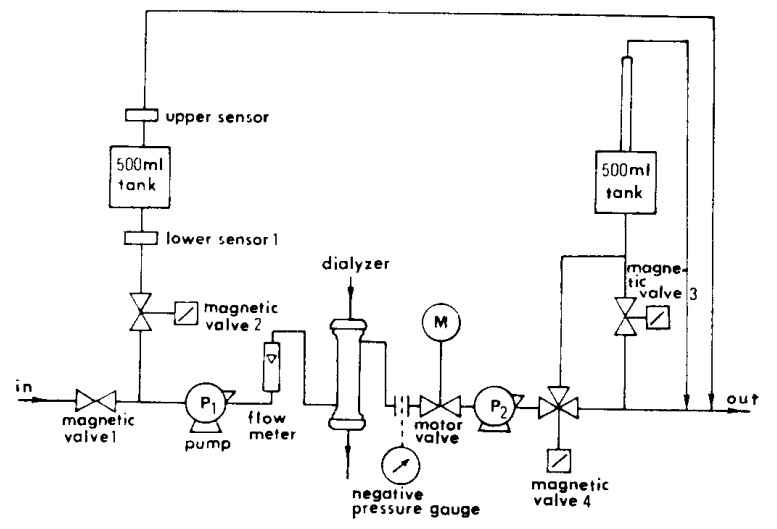

図 1 Reg-o-UF in Single-Pass 


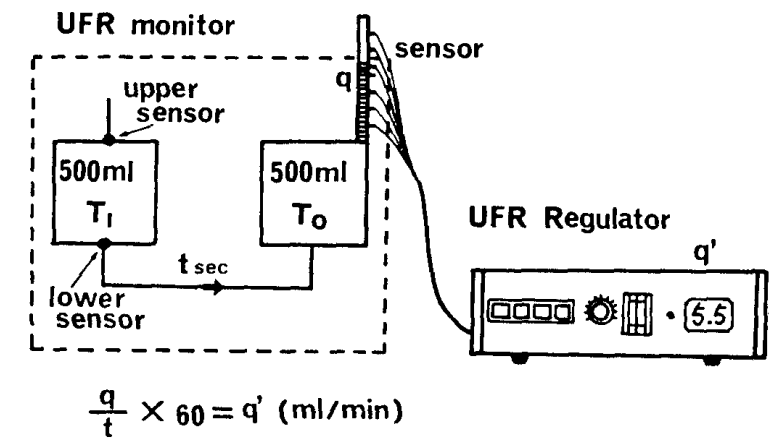

図 2 Principle of single-pass $\operatorname{Reg-o-UF}$

$\mathrm{t}$ 秒が測定される， $\mathrm{q}$ と $\mathrm{t}$ より，繁分の除水量 $\mathrm{qm} l$ が，レギュレータ部に表示される。レギュ レータ部では, マイクロコンピュータを備えて おり，設定值より測定された除水量が少ない場 合には限外演過圧を上げ，逆に多い場合には限 外㥁過圧を下げるように，信号を自動的に陰圧 制御用のモータバルブにフィードバックする. (図 2)

なお本装置の除水量の設定範囲は， $0 \sim 9.9$ $\mathrm{m} l / \mathrm{min}$ で, 測定周期は約 3 分である.

\section{試験方法}

1. in vitro 試験

in vitroに抢ける試験は，血液および透析液 として $37^{\circ} \mathrm{C}$ の水道水で代用し，前者は $200 \mathrm{~m} l$ $/ \mathrm{min}$ にて recirculate させ, 後者は $500 \mathrm{~m} l /$ min にて single pass させた. 設定除水量は, $3 \mathrm{ml} / \mathrm{min}, 6 \mathrm{ml} / \mathrm{min}, 9 \mathrm{ml} / \mathrm{min}$ で, 使用し た Dialyzer は AHFK K-101である。

\section{2. 臨床試験}

臨床試験は，当センタにおいて長期透析治療 中の患者10名を対象にして，本装置を使用し計 50回の血液透析を行った，透析条件は，血液流 量 $150 \mathrm{~m} \mathrm{l} / \mathrm{min}$, 透析液流量 $500 \mathrm{~m} \mathrm{l} / \mathrm{min}$ とし, 透析時間を 5 時間とした。設定除水量は，0〜 $9.9 \mathrm{ml} / \mathrm{min}$ の範囲内で設定した。使用した Dialyzer $は$, FILTRYZER B-1, AHFK K101, K-109MINI, KF-1, CF-1,500, TriEX -1である。

\section{結 果}

1. in vitro 試験

図 3 は，設定除水量を $6 \mathrm{~m} l / \mathrm{min}$ とし，表示 された除水量と陰圧を経時的に表わしたもので

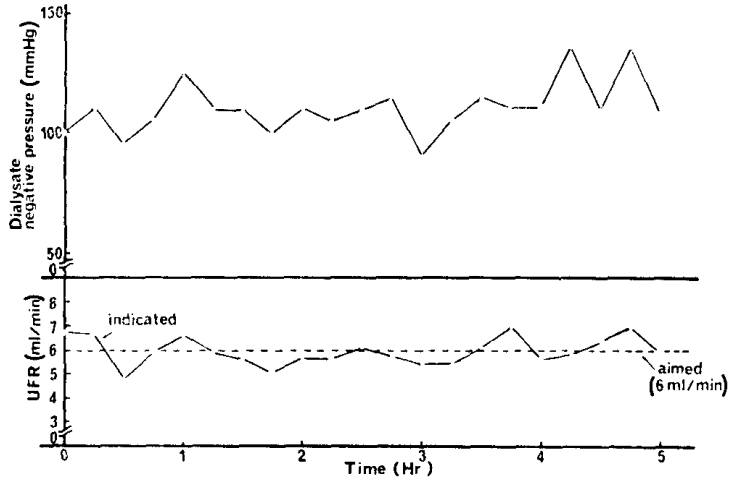

図3

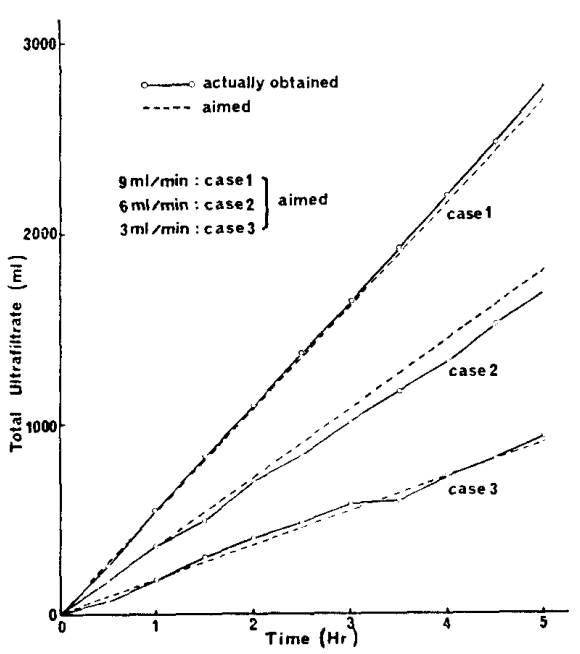

図 4

ある，本装置は，除水量を設定すると陰圧が $100 \mathrm{mmHg}$ からスタートし, その後連続的に測 定された除水量によって，目標量にそうように 限外演過圧が自動的に制御される。

図 4 は，設定除水量を $3 \mathrm{ml} / \mathrm{min}, 6 \mathrm{ml} / \mathrm{min}$ $9 \mathrm{ml} / \mathrm{min}$ とし, 本装置により実際えられた除 水量を経時的に表わしたものである，実際えら れた除水が点線の設定に追従していき，最終的 に目標值に達するようにコントロールされてい る.なお, in vitro 試験における目標值に対す る誤差は少なく，士5\%以内におさまった。

2. 臨床試験

図 5 は，本装置を使用したときの結果であり 目標値と体重減少量との定量誤差を表わしたも のである。患者の体重減少に透析中の体重増加 因子（食事，プライミング液, 回收液）および 体重減少因子（排浛，不感蒸泄）を補正したも のと，本装置の目標值に対する誤差は， $\pm 8 \%$ 以内になった。 


\begin{tabular}{ccc} 
Wt of removed water (aimed) & pt. T.S. & pt. T.Y. \\
minus (wt of priming solution & $2,700 \mathrm{gm}$ & $2,850 \mathrm{gm}$ \\
wt of infusion solution & 230 & 250 \\
wt of solution for blood retrieval & 100 & 100 \\
wt of food and water) & 450 & 100 \\
plus (Wt of feces and urine & 150 & 150 \\
Wt of insensibly lost water) & 2,070 & 2,550 \\
\hline theoretical B.W. change during 5hrs H.D. & 2,100 & 2,400 \\
actual B.W. change during 5hrs H.D. & + 1.4 & -5.9
\end{tabular}

図 5

なお，本装置使用時の尿素窒素，クレアチニ ン，尿酸の除去率は，それぞれ12例平均で 57.7 $\pm 8.8 \%, 54.2 \pm 7.1 \%, 61.8 \pm 8.5 \%$ でる。

\section{考察ならびに結語}

臨床試験における本装置の目標值に対する体 重減少量の誤差は， $\pm 8 \%$ で in vitro 試験の 誤差より大きい值となった，この值は，食事や 不感蒸泄量などの体重変化に影響を与える因子 の測定が，正確でないことによると推定され る。しかし，in vitroにおける成績は，士5\% で十分臨床に使用できるものと考光られる。な お，このよらな装置を使用した場合の透析効率 が問題になるが，尿素窒素，クレアチニン，尿 酸の除去率は，本装置使用によっても，十分な 透析効率がえられた。

以上のように，本装置は，連続的に除水量を 測定し，自動的に限外滤過圧をコントロールし ているため, Dialyzerの種類や，透析中の静脈 圧および血液流量の変化に対して，なんら影響 を受けることなく，的確な除水をえることがで きた。 今後, 除水能の高い high flux 型 Dialyzer の増加に伴っても，本装置はより安全な
透析を行うことが，できると考えられる。

付 議

\section{泉工医科工業 并 上 政 昭}

1）測定は透析液の流れを中断することなく 行えるのでしょうか.

2) 3 分間に 1 回計測するとのことですが， なぜ 3 分間かかるのでしょうか。また，測定中 透析液はバイパスによりダイアライザへ流され ているのでしょうか.

回 答

東京女子医大 星 野 敏 久

1）限外滤過量の測定は，透析液の流れを中 断していません。

2) 計測時間は, $\mathrm{Ti}$ タンク $(500 \mathrm{~m} l)$ に透 析液をためるのに 1 分, $\mathrm{Ti}$ タンクの透析液を に流すのに 1 分, Dialyzer.からの透析液を To タンクで受け，濾過量を表示するのに 1 分で, 合計約 3 分間かかります。

また測定中でも，透析液は常に Dialyzer に 流れています。 